\title{
Stable Isotopes in Greenhouse Gases from Soil: A Review of Theory and Application
}

\author{
Xiao-cong Zhu ${ }^{1}$, Dong-rui $\mathrm{Di}^{2}$, Ming-guo Ma ${ }^{1} \mathbb{C}$ and Wei-yu Shi ${ }^{1, *}$ \\ 1 Research Base of Karst Eco-Environments at Nanchuan in Chongqing of Ministry of Nature Resources \& \\ Chongqing Engineering Research Center for Remote Sensing Big Data, School of Geographical Sciences, \\ Southwest University, Chongqing 400715, China \\ 2 Graduate School of Global Environmental Studies, Sophia University, Tokyo 102-8554, Japan \\ * Correspondence: shiweiyu@swu.edu.cn
}

Received: 8 May 2019; Accepted: 5 July 2019; Published: 6 July 2019

\begin{abstract}
Greenhouse gases emitted from soil play a crucial role in the atmospheric environment and global climate change. The theory and technique of detecting stable isotopes in the atmosphere has been widely used to an investigate greenhouse gases from soil. In this paper, we review the current literature on greenhouse gases emitted from soil, including carbon dioxide $\left(\mathrm{CO}_{2}\right)$, methane $\left(\mathrm{CH}_{4}\right)$, and nitrous oxide $\left(\mathrm{N}_{2} \mathrm{O}\right)$. We attempt to synthesize recent advances in the theory and application of stable isotopes in greenhouse gases from soil and discuss future research needs and directions.
\end{abstract}

Keywords: greenhouse gas; stable isotope; soil respiration; isotope fractionation

\section{Introduction}

Climate change impacts on human lives and environmental safety, and has received considerable attention all over the world over the past few decades. Greenhouse gas emissions, principally changes in atmospheric carbon dioxide $\left(\mathrm{CO}_{2}\right)$, methane $\left(\mathrm{CH}_{4}\right)$, and nitrous oxide $\left(\mathrm{N}_{2} \mathrm{O}\right)$ concentrations, play an important role in global climate change, [1-3]. These greenhouse gases account for a lower proportion of the atmospheric composition than oxygen and nitrogen, but are important because they increase the energy input to the surface of the lower atmosphere by absorbing infrared radiation from the Earth's surface [4]. $\mathrm{CO}_{2}, \mathrm{CH}_{4}$, and $\mathrm{N}_{2} \mathrm{O}$ are the three primary greenhouse gases exchanged between the soil and the atmosphere [5], contributing about $80 \%$ of the current global radiative forcing [6], and these greenhouse gas emissions can be further enhanced by the impact of natural emissions (e.g., volcanic and hydrothermal) and human activities (e.g., fossil fuel combustion and agricultural practice) $[7,8]$.

Soil is a major source of greenhouse gases [9], where emissions of $\mathrm{CO}_{2}, \mathrm{CH}_{4}$, and $\mathrm{N}_{2} \mathrm{O}$ related to soil account for $35 \%, 47 \%$, and $53 \%$ of total annual $\mathrm{CO}_{2}, \mathrm{CH}_{4}$, and $\mathrm{N}_{2} \mathrm{O}$ emissions, respectively, including industry, agriculture, and so on [10]. Reducing soil greenhouse gas emissions is an effective pathway for global climate change mitigation [11,12]. However, the amount of greenhouse gas emission from soils, which needs to be determined the contribution to global carbon (C) budgets, is still not clear $[10,13]$. Stable isotope technologies will be necessary to enhance the quantitative assessment of soil constituents and reduce uncertainty in estimating the source of $C$ in the soil or atmosphere, and for assessing the different responses of soil and plants to environmental conditions. As one of the most powerful tools for understanding ecological and environmental processes, many stable isotope methods have been used to record environmental information and monitor the ecological process at different spatial and temporal scales, or address issues that are intractable using other methods [14]. The use of stable isotopes $\left({ }^{12} \mathrm{C}\right.$ and ${ }^{13} \mathrm{C},{ }^{14} \mathrm{~N}$ and ${ }^{15} \mathrm{~N},{ }^{16} \mathrm{O}$ and $\left.{ }^{18} \mathrm{O}\right)$ allows the identification of greenhouse gas components and drivers. Carbon isotopes are only a little fractionated in trophic chains and are therefore more suitable as a marker, whereas nitrogen $(\mathrm{N})$ isotopes are considerably fractionated in 
trophic chains, which makes them less convenient but allows their use as an integral index of many ecological processes $[15,16]$. Therefore, in this review, we will offer some insight into the greenhouse gases, including $\mathrm{CO}_{2}, \mathrm{CH}_{4}$, and $\mathrm{N}_{2} \mathrm{O}$, emitted from soil based on the perspective of stable isotopes, and integrate our knowledge on greenhouse gas exchange between the soil and atmosphere.

\section{Theory of Stable Isotope Techniques}

\subsection{Stable Isotopic Compositions}

Stable isotope ratios of elements in the $\mathrm{C}, \mathrm{N}$ and $\mathrm{O}$ components of plants and the soil environment often record and integrate ecological information relating to: (1) the identity of the ecological cycle processes that formed those elements' components; (2) the turnover rates of those formed elements' components processes; and (3) the environmental factor response during the decomposition or formation of organic and inorganic matter [17]. Many biogeochemical processes are often accompanied by changes in the concentration ratio between the stable isotopes of the elements $\mathrm{C}, \mathrm{N}$, and $\mathrm{O}$ (e.g., $\delta^{13} \mathrm{C}, \delta^{15} \mathrm{~N}$, and $\delta^{18} \mathrm{O}$, respectively) [18]. Using $\mathrm{C}, \mathrm{N}$, and $\mathrm{O}$ stable isotope ratios of $\mathrm{CO}_{2}, \mathrm{CH}_{4}$, and $\mathrm{N}_{2} \mathrm{O}$ may be an effective way of tracing the sources of fugitive emissions from soil respiration. Furthermore, isotope measurements can help in the attribution and quantification of surface sources because the magnitude of isotopic fractionation associated with each production pathway may differ [19]. Multiple stable isotopes exist for most chemical elements, and stable isotope ratios are expressed, using the $\delta$-notation in per mil (\%o), as the deviation of the sample's isotope ratio from the respective isotope ratio of the reference material [20], where

$$
\delta^{13} \mathrm{C}, \delta^{15} \mathrm{~N} \text { and } \delta^{18} \mathrm{O}=\left[\left(\mathrm{R}_{\text {SAMPLE }}-\mathrm{R}_{\text {STANDARD }}\right) / \mathrm{R}_{\text {STANDARD }}\right] \times 1000
$$

where $R_{\text {SAMPLE }}={ }^{13} \mathrm{C} /{ }^{12} \mathrm{C},{ }^{15} \mathrm{~N} /{ }^{14} \mathrm{~N}$, or ${ }^{18} \mathrm{O} /{ }^{16} \mathrm{O}$ of the sample and $\mathrm{R}_{\text {STANDARD }}={ }^{13} \mathrm{C} /{ }^{12} \mathrm{C}$ of the PDB standard (0.0112372), Air- $\mathrm{N}_{2}$ for N (0.003676) or Vienna Standard Mean Ocean Water (V-SMOW) for O [21].

All plants discriminate against ${ }^{13} \mathrm{C}$ during photosynthesis but the extent of this discrimination is a function of the photosynthetic pathway type [22-24]. Terrestrial plants can be divided into two types of plants, $C_{3}$ and $C_{4}$, depending on the type of photosynthetic pathway [25]. Terrestrial plants that utilize the $\mathrm{C}_{3}$ (Calvin cycle) pathway have $\delta^{13} \mathrm{C}$ values ranging from approximately $-35 \%$ o to $-20 \%$, plants the utilize the $\mathrm{C}_{4}$ (Hatch-Slack) photosynthesis pathway have higher $\delta^{13} \mathrm{C}$ values ranging from about $-19 \%$ o to $-9 \%$, and the average $\delta^{13} \mathrm{C}$ values of $C_{3}$ and $C_{4}$ plants are approximately $-27 \%$ ond $-13 \%$, respectively [26,27]. Soil microbial and bacterial decomposition is one of the most important sources of greenhouse gases, using stable isotopes to trace soil nitrification and denitrification processes [28]. Therefore, the source of greenhouse gas components in the soil and atmosphere can be easily traced by using stable isotopes in the process of the ecosystem C cycle.

\subsection{Soil $\mathrm{CO}_{2}, \mathrm{CH}_{4}$ and $\mathrm{N}_{2} \mathrm{O}$ Stable Isotope Signatures}

$\mathrm{CO}_{2}$. The total emission of $\mathrm{CO}_{2}$ from soils is one of the most important fluxes in the terrestrial ecosystem $\mathrm{C}$ cycle, controlling global $\mathrm{C}$ budgets and the ecological balance [29]. Soil $\mathrm{C}$ sequestration is also an effective method of reducing the atmospheric concentration of greenhouse gases, defined as the process of removing $C$ from the atmosphere and depositing it in a reservoir (Figure 1) [30,31]. There are two different ways to exchange $\mathrm{C}$ between the soil and atmosphere, including direct and indirect exchange. First, the direct exchange of atmospheric greenhouse gases transforms these gases into soil inorganic carbon (SIC) compounds, and soil $\mathrm{C}$ is absorbed by roots and discharged directly into the atmosphere through plants. Second, in the indirect exchange of atmospheric $\mathrm{CO}_{2}$, atmospheric $\mathrm{CO}_{2}$ is incorporated into plant tissue through the photosynthetic process, and subsequently, part of the plant biomass is indirectly sequestered as soil organic carbon (SOC) during decomposition processes [1]. SOC is decomposed by microorganisms to form $\mathrm{CO}_{2}$, which is returned to the atmosphere [32]. $\mathrm{CO}_{2}$ is produced in the soil through a series of microbial processes and residual soil organic matter (SOM) 
enriches ${ }^{13} \mathrm{C} . \mathrm{CO}_{2}$ is continuously transported to the overlying atmosphere via molecular diffusion and enriches ${ }^{12} \mathrm{C}$ [33]. However, the $\mathrm{CO}_{2}$ emitted by the soil is not all derived from the decomposition of SOM, due to the soil C cycle being a complex and slow process, and other soil C sources, including $\mathrm{C}$ pools in the soil, heterotrophic or autotrophic organisms, root respiration, and turnover rates of $\mathrm{C}$ pools [26]. Therefore, using the information provided by the soil, it is still difficult to determine whether the soil is a $\mathrm{C}$ source or a $\mathrm{C}$ sink for atmospheric $\mathrm{CO}_{2}$. Previous research has reported the $\delta^{13} \mathrm{CO}_{2}$ (the isotope ratio of $\mathrm{CO}_{2}$ ) values of $\mathrm{C}_{3}$ plants varied between $-23 \%$ o and $-40 \%$, and $\mathrm{C}_{4}$ plants varied between $-9 \%$ and $-19 \%$ [34]. Drewer et al. [35] estimated that the $\delta^{13} \mathrm{CO}_{2}$ values of Miscanthus ( $C_{4}$ plants) ranged from $-9 \%$ o to $-11 \%$, and the farmland ranged from $-22 \%$ o to $-29 \%$ o after one year of Miscanthus removal. Pendall and King [36] found that the decomposition rate of SOM is high and the $\delta^{13} \mathrm{C}$ values are low in the initial stage of topsoil $\mathrm{C}$ sequestration, and high $\delta^{13} \mathrm{C}$ values were observed in subsoils. In addition, the subsoil isotope values were generally higher than the topsoil in $\mathrm{CO}_{2}$ respiration. They suggested that microbial activity first consumes fresh residue in the topsoil, resulting in ${ }^{13} \mathrm{C}$ depletion, and ${ }^{13} \mathrm{C}$ enrichment of the subsoil.

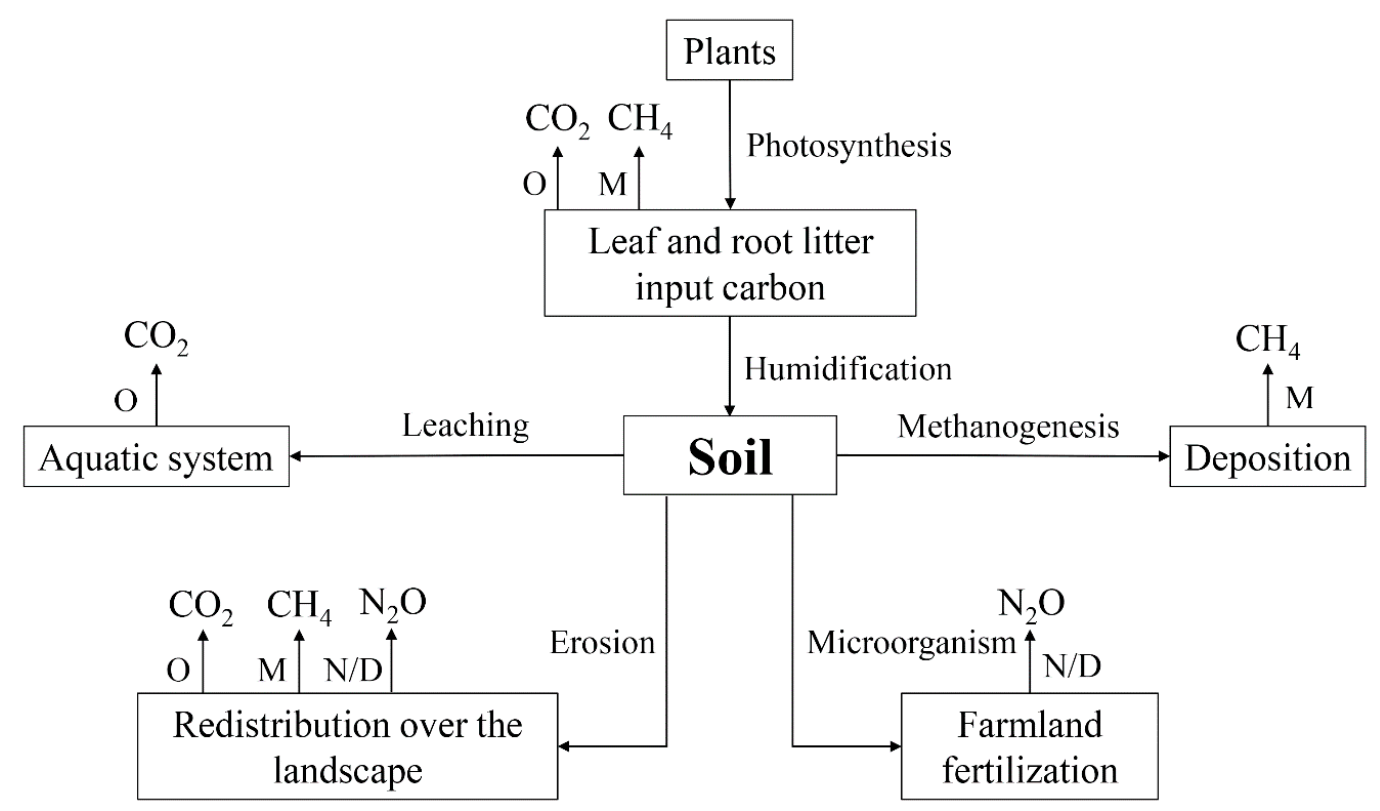

Figure 1. Processes of soil greenhouse gas emissions (modified from Rastogi et al. [3]). O, oxidation; M, methanogenesis; N/D, nitrification and denitrification.

$\mathrm{CH}_{4}$. Rice fields are one of the most important anthropogenic emission sources of atmospheric $\mathrm{CH}_{4}$ and contribute about $11 \%-13 \%$ of the total global emissions [37-39]. Rice fields play a key role in the increase of atmospheric $\mathrm{CH}_{4}$ concentration and proper management can result in the soil acting as a $\mathrm{C}$ sink $[40,41]$. Stable isotope fractionation happens in the production, oxidation, and transport of $\mathrm{CH}_{4}$ emission processes: (1) the preferential consumption of ${ }^{12} \mathrm{CH}_{4}$ by methanotrophic bacteria for $\mathrm{CH}_{4}$ production; (2) the ${ }^{12} \mathrm{CH}_{4}$ is utilized faster than ${ }^{13} \mathrm{CH}_{4}$ by methanotrophic bacteria for $\mathrm{CH}_{4}$ oxidation, and the enrichment of ${ }^{13} \mathrm{C}$ in the residual $\mathrm{CH}_{4} ;(3){ }^{13} \mathrm{CH}_{4}$ is transported significantly slower than ${ }^{12} \mathrm{CH}_{4}$, leading to an isotope ratio difference [42-44]. Zhang et al. [37] observed the changes in the processes of $\mathrm{CH}_{4}$ emission and the $\delta^{13} \mathrm{C}$ value from fields and via paddy plants during the rice season in China (Figure 2). The rice growing season lasts about 113 days, and the $\mathrm{CH}_{4}$ emission changed significantly over different periods. The $\mathrm{CH}_{4}$ flux value with different days (D) appeared in the following order: D50 > D70 > D88 > D20 > D108. However, $\delta^{13} \mathrm{C}$ had the opposite trend in $\mathrm{CH}_{4}$ flux, with the highest and lowest values appearing on D108 $(-68.7 \%$ o) and D50 $(-61.5 \%$ o $)$, respectively. It is most noticeable that there was a significant negative correlation between $\mathrm{CH}_{4}$ emissions and the $\delta^{13} \mathrm{C}$ value. Similar $\delta^{13} \mathrm{C}$ values and patterns of variation were also observed in previous studies (Table 1 ). The change of 
$\delta^{13} \mathrm{C}$ occurs in the $\mathrm{CH}_{4}$ emission processes, including production, oxidation and transport. The ${ }^{13} \mathrm{C}$ is enriched at the beginning of the season. Subsequently, a rapid depletion in ${ }^{13} \mathrm{C}$ occurs and reaches the lowest value, being mostly depleted in ${ }^{13} \mathrm{C}$ in the middle of the season. During the late period of the season, ${ }^{13} \mathrm{C}$ becomes enriched again.

Table 1. Overview of $\delta^{13} \mathrm{C}$ values of $\mathrm{CH}_{4}$ emissions in different countries from rice fields ${ }^{\text {a. }}$

\begin{tabular}{cccc}
\hline Location & Seasonal Coverage & $\left.\mathbf{\delta}^{\mathbf{1 3}} \mathbf{C H}_{\mathbf{4}} \mathbf{( \% o}\right)$ & Reference \\
\hline Japan & throughout the season & -68 to -48 & Uzaki et al., 1991 [45] \\
Japan & throughout the season & -72 to -56 & Tyler et al., 1994 [46] \\
China & throughout the season & -71 to -52 & Bergamaschi, 1997 [47] \\
& throughout the season & -71 to -58 & \\
America & throughout the season & -66 to -61 & Chanton et al., 1997 [48] \\
America & throughout the season & -58 to -53 & Tyler et al., 1997 [49] \\
America & throughout the season & -63 to -46 & Bilek et al., 1999 [42] \\
& throughout the season & -62 to -48 & Marik et al., 2002 [50] \\
Italy & throughout the season & -67 to -47 & \\
& throughout the season & -65 to -53 & Krüger and Frenzel, 2003 [51] \\
Italy & throughout the season & -73 to -58 & Conrad and Klose, 2005 [52] \\
Germany & throughout the season & -68 to -61 & Zhang et al., 2012 [53] \\
China & throughout the season & -71 to -47 & Zhang et al., 2014 [54] \\
China & throughout the season & -61 to -59 &
\end{tabular}

a Adapted from the study of Marik et al. [50] and Zhang et al. [53].
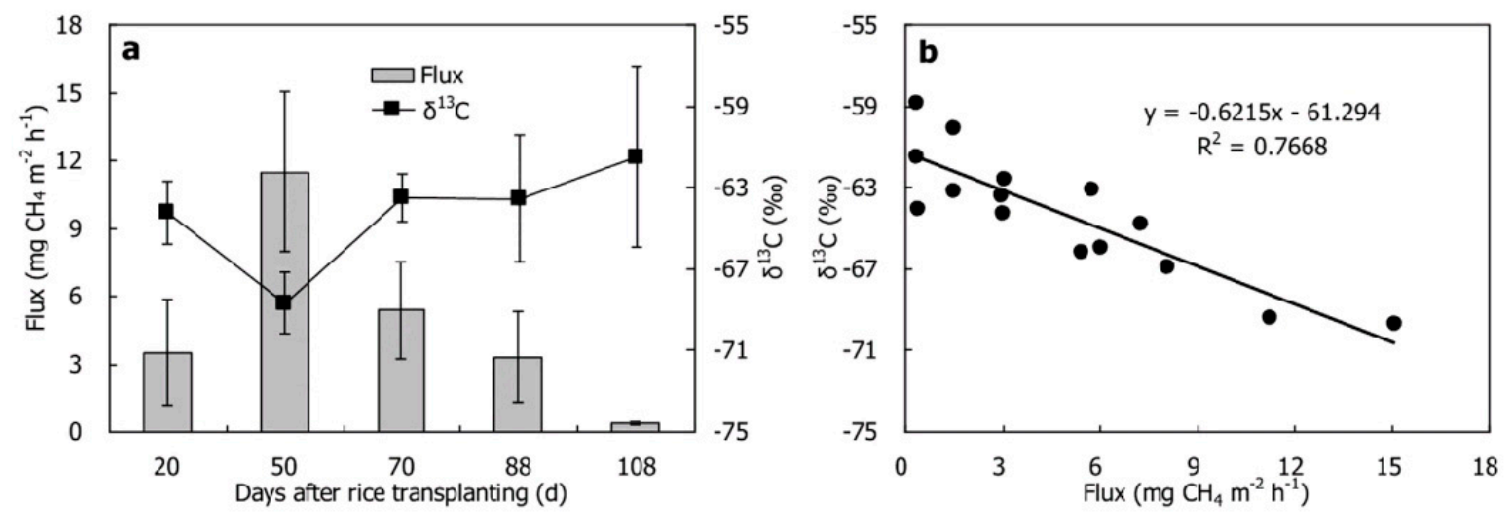

Figure 2. The relationship between $\mathrm{CH}_{4}$ and $\delta^{13} \mathrm{C}$ in time evolution mode (a) and the correlation between them (b) (from Zhang et al. [37]).

$\mathrm{N}_{2} \mathrm{O} . \mathrm{N}_{2} \mathrm{O}$ is a potent greenhouse gas, and its content in the atmosphere affects the recovery of the ozone layer and contributes to about $6 \%$ of the global greenhouse effect $[55,56]$. Among the sources of anthropogenic $\mathrm{N}_{2} \mathrm{O}$ emissions, roughly $58 \%$ are related to agricultural production systems [57]. According to the IPCC (Intergovernmental Panel on Climate Change) [13], soil ecosystems are the most important source of global $\mathrm{N}_{2} \mathrm{O}$ emissions, representing about $65 \%$ of the total amount of $\mathrm{N}_{2} \mathrm{O}$ emitted into the atmosphere, especially, farmland $\mathrm{N}$ fertilizer, which accounts for the largest proportion. An important source of $\mathrm{N}_{2} \mathrm{O}$ in soils is related to microbiological processes: bacterial nitrification $\left(\mathrm{N}_{2} \mathrm{O}\right.$ as a byproduct) and denitrification $\left(\mathrm{N}_{2} \mathrm{O}\right.$ as an intermediate product) [28,58]. Nitrification includes autotrophic nitrification (microbes use $\mathrm{CO}_{2}$ as a $\mathrm{C}$ source) and heterotrophic nitrification (microorganisms use organic carbon as a $\mathrm{C}$ source), and the heterotrophic nitrification substrate is organic nitrogen or inorganic nitrogen. $\mathrm{N}_{2} \mathrm{O}$ production in soil during autotrophic nitrification is traditionally considered to be minor in comparison with denitrification [59]. Nitrification is a multistep process, involving the continuous oxidation of ammonia $\left(\mathrm{NH}_{3}\right)$ under aerobic conditions: $\mathrm{NH}_{3} \rightarrow \mathrm{NH}_{2} \mathrm{OH} \rightarrow\left(\mathrm{N}_{2} \mathrm{O}\right) \rightarrow \mathrm{NO}_{2}^{-} \rightarrow \mathrm{NO}_{3}^{-}$, and denitrification is a series of processes involving a 
successive reduction of nitrate under anaerobic conditions: $\mathrm{NO}_{3}^{-} \rightarrow \mathrm{NO}_{2}^{-} \rightarrow \mathrm{NO} \rightarrow \mathrm{N}_{2} \mathrm{O} \rightarrow \mathrm{N}_{2}$ [60-62]. The atmospheric concentration of $\mathrm{N}_{2} \mathrm{O}$ has been growing exponentially, mainly due to the growing food demand of the human population and increased use of chemical fertilizers, especially the use of nitrogen-based fertilizers, stimulating soil microbial nitrification and denitrification [63]. Stable isotopes have become a useful research tool for $\mathrm{N}_{2} \mathrm{O}$ production processes, for inferring the sources, production and consumption processes, and better estimating the atmosphere $\mathrm{N}_{2} \mathrm{O}$ budget [62]. The stable isotope ratio of $\mathrm{N}_{2} \mathrm{O}$ quantifies the contribution of denitrification to $\mathrm{N}_{2} \mathrm{O}$ flux and provides the basis for determining the proportion of $\mathrm{N}_{2} \mathrm{O}$ derived from aerobic nitrifying versus anaerobic denitrifying bacteria [64]. The $\delta^{15} \mathrm{~N}$ composition is considered to be a relative contribution of nitrification and denitrification to the soil $\mathrm{N}_{2} \mathrm{O}$ emission. Previous research estimates of the ${ }^{15} \mathrm{~N}$ isotope effect $(\varepsilon)$ (product-substrate) for $\mathrm{N}_{2} \mathrm{O}$ production by the soil denitrification process vary from $-10 \%$ o to $-45 \%$ o [65-68]. Snider et al. [69] reported that for the upland and wetland temperate forest soils' stable isotopic composition of $\delta^{15} \mathrm{~N}-\mathrm{N}_{2} \mathrm{O}$ by denitrification under different moisture and temperature conditions, the wetland soil exhibited consistently larger $\mathrm{N}_{2} \mathrm{O}$ production rates compared to upland soils, and the ${ }^{15} \mathrm{~N}$ isotope effect ranged from $-20 \%$ o to $-29 \%$.

\subsection{Environmental Factors Affect the Isotope Signal of Soil Greenhouse Gases}

\subsubsection{Temperature and Precipitation}

The formation of SOM is mainly derived from plant litter and rhizomes, and the isotope ratio values of SOM records information on vegetation and soil $\mathrm{C}$ cycle processes, where plant and soil $\delta^{13} \mathrm{C}$ and $\delta^{15} \mathrm{~N}$ signals are closely related. The positive relationship between soil $\delta^{13} \mathrm{C}$ and plant $\delta^{13} \mathrm{C}$ revealed that plant litter and rhizomes may be sources of SOM [70]. The distribution of plants is mostly determined by climate, such as the $\mathrm{C}_{3}$ plant, which dominates in the high latitude tundra and grassland, while $\mathrm{C}_{4}$ plants are often distributed in high light intensity and semiarid environments, and crassulacean acid metabolism (CAM) plants are only present in desert ecosystems [71]. Climatic factors control the growth and survival of plants and influence the isotopic signature of ecosystem respiration. Zhang et al. [72] recognized that the $\delta^{13} \mathrm{C}$ of soil $\mathrm{CO}_{2}$ emissions was negatively correlated with temperature after farmland was afforested in central China. According to Vitória et al. [73], precipitation and $\delta^{15} \mathrm{~N}$ values are negatively correlated until the point of soil waterlogging. Lee et al. [71] suggested that changes of $\delta^{13} \mathrm{C}$ in SOM obviously follow those of the plant zone in arid and semiarid central East Asia. The climate in central East Asia is mainly controlled by northern moisture, especially precipitation. Although temperature plays an important role in plant growth, the latter has not been caused by the higher temperature, but by the higher precipitation, in the central East Asia region. In addition, besides temperature and precipitation, parameters that influence the isotopic composition of soils include the plant photosynthetic efficiency, sunlight duration, altitude, and concentration of atmospheric $\mathrm{CO}_{2}$ [74]. Knowledge of the response of soil greenhouse gas production, transport, emissions, and sequestration pathways to environmental conditions affords the potential for controlling global warming by, for example, control of the timing and scale of land use change, and mitigating changes in the regional microclimate.

\subsubsection{Soil Physical Factors}

The physical and chemical properties of soil are mainly affected by land use changes, which affect soil aggregate formation and stimulate soil microbial community repeated processing. For example, the conversion of degraded farmland to vegetation usually increases inputs of fresh organic matter and rhizome exudates, which in turn can change the underground soil structure and eventually affect the stable isotope ratio of soil [75]. Soil texture (coarse and fine particle size) is one of the most important controls of $\delta^{13} \mathrm{C}$. Wynn and Bird [76] reported that the $<63 \mu \mathrm{m}$ (percent of mineral particles) fraction is more ${ }^{13} \mathrm{C}$ enriched than bulk soil, and the $>63 \mu \mathrm{m}$ fractions are more ${ }^{13} \mathrm{C}$ depleted in Australia. Koch and Fox [77] investigated the relationship between $\delta^{13} \mathrm{C}$ and $\delta^{15} \mathrm{~N}$ values and soil depth changes after 
grazing exclusion on the central Californian coast, and found that the $\delta^{13} \mathrm{C}$ values did not change with depth and there was an increase in $\delta^{15} \mathrm{~N}$ values with depth in the fine soil. However, this conclusion is inconsistent with the results of previous studies [36], which may be due to significant differences in the soil respiration rates and subsurface soil structure for various vegetation types.

\subsubsection{Soil Microbial Process}

Soil microorganism metabolic processes are responsible for driving the belowground biogeochemical cycling of elements in the terrestrial biosphere [78]. However, soil microorganism communities' growth and activities are often limited by environmental change, and they are more sensitive to changes in temperature and precipitation [76]. Microbial growth also depends on resource availability, for instance, the input of SOM is closely associated with aboveground plant types. Plants further affect the microbial community composition and function by affecting available soil aggregate, nutrients, temperature, and moisture [79]. For instance, previous research indicated that the $\delta^{13} \mathrm{C}$ of soil $\mathrm{CO}_{2}$ emissions was positively correlated with the $\delta^{13} \mathrm{C}$ of microbial biomass and negatively correlated with soil temperature [70,71]. Namely, the contribution of soil microbes to soil greenhouse gas production and emissions changes seasonally. Hornibrook et al. [80], based on a trace of $\delta^{13} \mathrm{CH}_{4}$ in temperate zone wetlands, confirmed that microbial methanogenics obtained by the acetate fermentation pathway are more predominant in certain anoxic, organic-rich soils. Morse and Bernhardt [81] also noted that hypoxia provides the ideal low oxygen conditions conducive to microbial $\mathrm{N}_{2} \mathrm{O}$ production by using ${ }^{15} \mathrm{~N}$ tracers from nitrification and denitrification. Therefore, an anaerobic environment may be one of the most important conditions in the process of the soil microbial production of greenhouse gases.

\section{Stable Isotope Application}

\subsection{Stable Isotope Tracer}

Generally, stable isotope fractionation is achieved through the transition from one phase to another by organic and inorganic compounds, and the long-term dynamics of the ecosystem are reconstructed using stable isotope ratio differences [18]. Stable isotopes can record information on changes in greenhouse gas production, transport, and emissions by isotope fractionation during the soil ecosystem process [82]. Stable isotopes in greenhouse gas from soil are considered a promising option for tracking the source of atmospheric greenhouse gases [17]. The stable isotope is a potentially powerful tool for studying exchange processes of greenhouse gases between the soil and atmosphere. Isotopes can be used as evidence of $\mathrm{CO}_{2}, \mathrm{CH}_{4}$, and $\mathrm{N}_{2} \mathrm{O}$ production and oxidation [83], organic matter and inorganic matter accumulation [84], and environmental conditions affecting the fractionation during greenhouse gas generation [85]. Stable isotopes have been widely used in biological processes in ecosystems over the past few decades, and we have a clear understanding of the mechanisms of isotopic fractionation.

\subsection{Application of Stable Isotopes in a Soil System}

Ecosystem respiration partitioning. Ecosystem $C$ exchange flux is the result of $C$ uptake during the daytime by net photosynthesis and $C$ losses by net respiration [86]. Photosynthesis can sequester $55 \%$ of the $\mathrm{C}$ in terrestrial ecosystems per year, and soil respiration accounts for approximately $69 \%$ of the total ecological respiration [87]. The total ecological respiration is a composite flux, including plant respiration (leaves and canopy) and soil respiration (autotrophic respiration and heterotrophic respiration) [88]. Partitioning total ecological respiration into plant (leaves and canopy) and soil respiration is important for evaluating the relative contribution of plants and soils to $C$ sinks and presenting an accurate quantification of plant-soil-climate interactions. Because photosynthesis changes isotopic fractionation, plant and soil respiration have different $\mathrm{CO}_{2}$ isotope signatures [89-92], and using ${ }^{13} \mathrm{C}_{-}-\mathrm{CO}_{2}$ and ${ }^{18} \mathrm{O}-\mathrm{CO}_{2}$ measurements, combined with $\mathrm{C}$ eddy flux and concentration measurements, for the partitioning may be a good option [88,90]. Isoflux-based isotopic flux partitioning (IFP) can potentially be used to conduct the partitioning for separate soil respiration from ecological respiration [86]. 
In addition, isotope ratio infrared spectroscopy (IRIS) and isotope ratio mass spectrometry (IRMS) also provide an effective method for measuring trends in the isotopic compositions of plant respiration and soil respiration [93]. Stable isotopes make up for the shortcomings of eddy covariance techniques that cannot separate ecological respiration components. As a tracer, stable isotopes provide a unique method for discriminating plant respiration and soil respiration in total ecological respiration.

Soil respiration component. The soil C cycle is strongly linked to plant metabolism (e.g., recent production of plant litter) and soil microbial activity. Soil produces $\mathrm{CO}_{2}$ primarily through rhizosphere respiration and microbial respiration (e.g., autotrophic and heterotrophic respiration). Although the eddy covariance technique and micrometeorological techniques can achieve total $\mathrm{CO}_{2}$ efflux, it is difficult to determine $\mathrm{CO}_{2}$ from different sources, especially $\mathrm{CO}_{2}$ produced by the rhizosphere and microbial respiration [26]. This is also one of the main challenges facing current ecosystem $C$ cycle research. Stable isotope technology is an alternative method of measuring $\mathrm{CO}_{2}$ that reduces soil and plant disturbances. Pulsed or continuous labeling of plants and soil using stable isotopes can accurately distinguish between $\mathrm{CO}_{2}$ produced by the rhizosphere and microbial respiration. Generally, the rhizosphere and microbial respiration processes are often accompanied by changes in the concentration ratio between the stable isotopes of the element $C$ [18]. This carbon stable isotope ratio difference can be used to quantify and distinguish between rhizosphere and microbial respiration. It is advantageous to distinguish soil respiration components in the short term. However, ${ }^{13} \mathrm{C}$ may deplete rapidly and the isotope signatures of organic matter become similar to labeled plants over time [94]. Therefore, it is necessary to repeat the labeling of stable isotopes of soil and plants over a relatively long period of soil respiration.

Rhizosphere process. The rhizosphere process is one of the most important pathways for $\mathrm{CH}_{4}$ emissions and the $\mathrm{CH}_{4}$ produced by the soil is transported to the atmosphere by entering the roots of the plant [95]. $\mathrm{CH}_{4}$ production in soil is very sensitive to changes in rhizosphere oxygen concentration, and $\mathrm{CH}_{4}$ emissions change with the seasons. Therefore, an accurate understanding of the soil $\mathrm{CH}_{4}$ nutrient community structure and its activity is of great significance for the exploration of $\mathrm{CH}_{4}$ production and emission processes [96]. Methanogen requires strict anaerobic conditions, and rice fields are an important source of methane emissions. The phospholipid fatty acid-stable isotope probing (PLFA-SIP) methodology has been widely used in the tracking of rhizosphere microbial community structure changes [78]. The plant rhizosphere is closely related to soil C sequestration, which also depends on photosynthesis intensity, and rhizosphere microorganisms have different absorption characteristics for photosynthesis production [97]. Therefore, continuous pulse labeling of rice using ${ }^{13} \mathrm{C}-\mathrm{CO}_{2}$ is used to track bacteria that affect the production of $\mathrm{CH}_{4}$ by the rhizosphere microbial community. In addition, the microbial community is primarily regulated by nutrient availability in the soil and roots [98]. $\mathrm{N}$ addition and nutrient use efficiency are important factors affecting rhizosphere microbial activity [99]. Changes in stable isotope ratios $\left(\delta^{15} \mathrm{~N}\right)$ can reflect soil $\mathrm{N}$ availability and plant nutrient use efficiency due to differences in the $\mathrm{N}$ fixation capacity of microbes and plant roots.

Rhizosphere priming effects. Plant leaves and root litter are the main sources of SOM, providing a labile substrate for soil microbial decomposition. The addition of organic matter causes rapid changes in the SOM turnover rate in the short term, and this change generally occurs in the rhizosphere (rhizosphere priming effects) [100]. Root exudates accelerate the decomposition of organic matter by increasing microbial activity, releasing more inorganic nitrogen, and thereby forming a priming effect [101,102]. Namely, there is a positive feedback relationship between SOM and the rhizosphere [103], and the effectiveness of SOM decomposition depends on microbial biomass mediated conversion [104]. Through the continuous and repeated labeling of plants with ${ }^{13} \mathrm{C}$-depleted $\mathrm{CO}_{2}$ and ${ }^{15} \mathrm{~N}$-enriched soil, we can differentiate root $\mathrm{N}$ sequestration and microbial nitrogen sequestration effectiveness, and root-derived $\mathrm{CO}_{2}$ from $\mathrm{SOM}$-derived $\mathrm{CO}_{2}$ [105]. The difference in stable isotope ratios clarifies the relative importance of microbes, SOM, and roots to rhizosphere priming effects [106]. In addition, the rhizosphere priming effect may be affected by changes in abiotic factors in the soil environment (e.g., elevated $\mathrm{CO}_{2}$, soil type, and temperature) [107-110]. Abiotic factors further influence the rate and 
intensity of rhizosphere priming effects by affecting biological factors [108]. The rhizosphere priming effect is a complex multi-factor correlation process, and the stable isotope continuous labeling method is essential for estimating the contribution of $\mathrm{CO}_{2}$ emissions from individual sources [26].

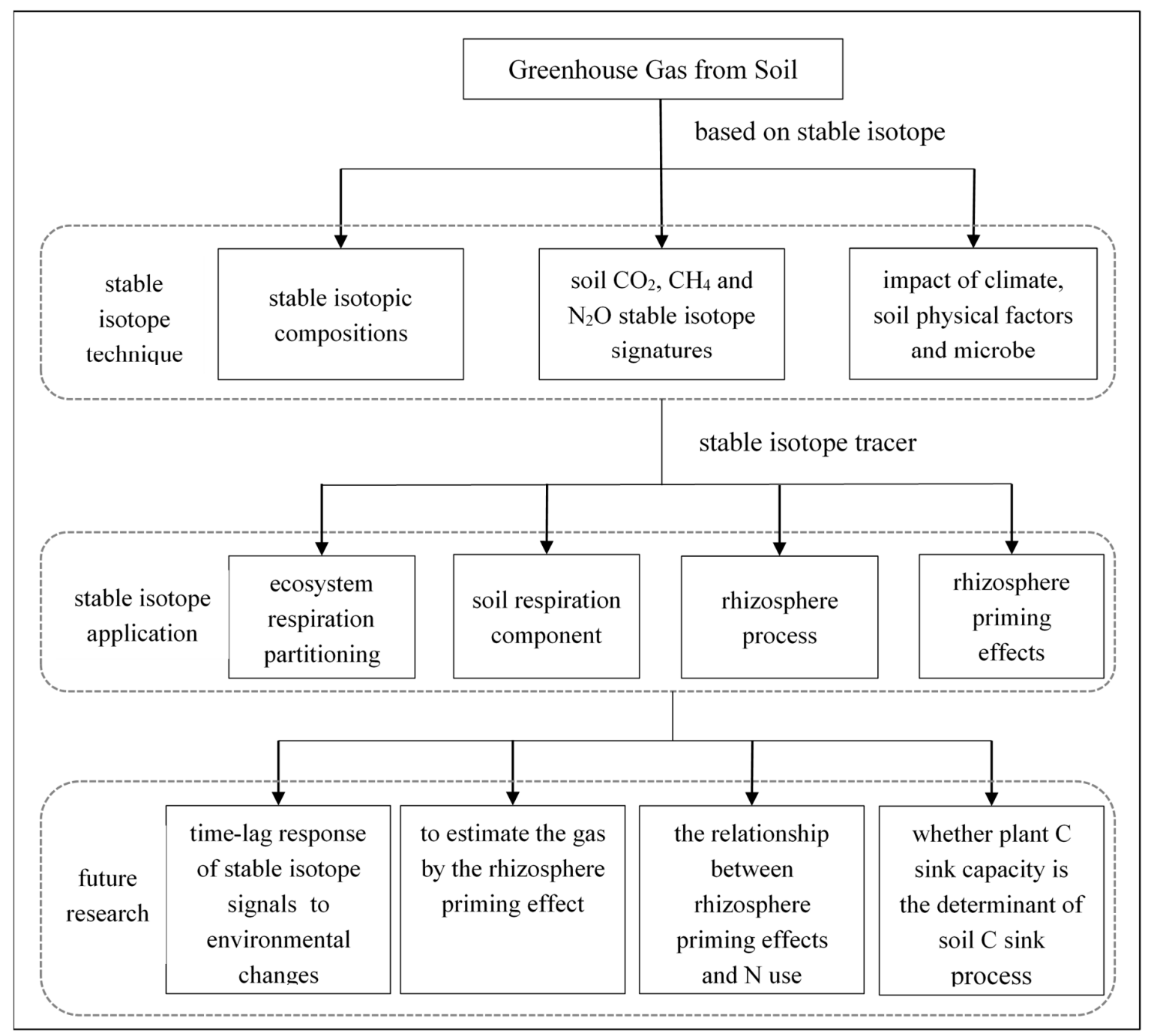

Figure 3. Overview of processes determining the stable isotope signals of greenhouse gas from soil.

\section{Future Research for Soil Greenhouse Gas Emissions}

This review may provide a bridge to determine the strength of coupling between soil greenhouse gas emissions and atmosphere change, by tracking the gas exchange processes of terrestrial ecosystems with stable isotope signatures (Figure 3). The production, transport, and emission of greenhouse gases in the soil is a complex chemical and microbiological process, which is affected by temperature, precipitation, soil moisture, soil properties, soil erosion, and manual management. In addition, the feedback effect of vegetation types on soil $\mathrm{C}$ and $\mathrm{N}$ sequestration is not clear, due to the complexity of the vegetation community composition and succession [111]. Isotopic monitoring of soil $\mathrm{C}$ and $\mathrm{N}$ fractionations, as well as greenhouse gas tracking, has been widely applied over most of the soil-atmospheric gas cycle. However, we still need to consider the interaction of soil temporal-spatial changes, microbial species distribution and tectonically active areas [112,113]. Therefore, at least three issues have been proposed that need to be focused on in future studies, including: (1) addressing the fact that the time-lag response of stable isotope signals to environmental changes during soil-atmosphere C exchange is rarely studied; (2) estimating the greenhouse gas from soil evolved by the rhizosphere priming effect, especially the separation of rhizosphere SOM and N fertilizer in farmland, where 
using $\mathrm{C}$ and $\mathrm{N}$ isotope labeling may be the best option; (3) exploring the relationship between changes in rhizosphere priming effects and $\mathrm{N}$ use efficiency ( $\mathrm{N}$ competition between tree species and microorganisms); and (4) based on greenhouse gas exchange of soil ${ }^{13} \mathrm{C}$ measurements, determining whether the plant $C$ sink capacity is the determinant of the soil $C$ sink. The deeply derived gasses composition could affect soil gas composition in tectonically active areas, and our review focuses only on earth's surface. Therefore, we need to discuss deeply derived gasses further.

Author Contributions: All of the authors were involved in the preparation, revision and review of the manuscript. Conceptualization, W.-y.S., and D.-r.D.; Writing—original draft preparation, X.-c.Z.; Writing—review and editing, M.-g.M. and W.-y.S.; help and discussion, M.-g.M. and W.-y.S.

Funding: This research was funded by the Chongqing Basic Research and Frontier Exploration Program (No. cstc2018jcyjAX0187), the Fundamental Research Funds for the Central Universities (Nos. SWU116087 and XDJK2017B013), and the National Natural Science Foundation of China (No. 41830648).

Acknowledgments: We would like to thank the anonymous reviewers and editors for their valuable comments and suggestions.

Conflicts of Interest: The authors declare no conflict of interest.

\section{References}

1. Crutzen, P.J.; Heidt, L.E.; Krasnec, J.P.; Pollock, W.H.; Seiler, W. Biomass burning as a source of atmospheric gases $\mathrm{CO}, \mathrm{H}_{2}, \mathrm{~N}_{2} \mathrm{O}, \mathrm{NO}, \mathrm{CH}_{3} \mathrm{Cl}$ and COS. Nature 1979, 282, 253. [CrossRef]

2. Gu, L.; Chen, J.; Xu, C.; Kim, J.; Chen, H.; Xia, J.; Zhang, L. The contribution of internal climate variability to climate change impacts on droughts. Sci Total Environ. 2019, 684, 229-246. [CrossRef] [PubMed]

3. Metz, B.; Davidson, O.; Bosch, P.; Dave, R.; Meyer, L. Climate change 2007: Mitigation of climate change. In Contribution of Working Group III to the Fourth Assessment Report of the Intergovernmental Panel on Climate Change; Cambridge University Press: Cambridge, UK, 2007.

4. Lashof, D.A.; Ahuja, D.R. Relative contributions of greenhouse gas emissions to global warming. Nature 1990, 344, 529-531. [CrossRef]

5. Chen, Y.; Chen, G.; Ye, Y. Coastal vegetation invasion increases greenhouse gas emission from wetland soils but also increases soil carbon accumulation. Sci. Total Environ. 2015, 526, 19-28. [CrossRef]

6. Stocker, T.F.; Qin, D.; Plattner, G.-K.; Alexander, L.V.; Allen, S.K.; Bindoff, N.L.; Bréon, F.-M.; Church, J.A.; Cubasch, U.; Emori, S. Technical summary. In Climate Change 2013: The Physical Science Basis. Contribution of Working Group I to the Fifth Assessment Report of the Intergovernmental Panel on Climate Change; Cambridge University Press: Cambridge, UK, 2013; pp. 33-115.

7. Anderegg, W.R.; Prall, J.W.; Harold, J.; Schneider, S.H. Expert credibility in climate change. Proc. Natl. Acad. Sci. USA 2010, 107, 12107-12109. [CrossRef] [PubMed]

8. Venturi, S.; Tassi, F.; Magi, F.; Cabassi, J.; Ricci, A.; Capecchiacci, F.; Caponi, C.; Nisi, B.; Vaselli, O. Carbon isotopic signature of interstitial soil gases reveals the potential role of ecosystems in mitigating geogenic greenhouse gas emissions: Case studies from hydrothermal systems in Italy. Sci. Total Environ. 2019, 655, 887-898. [CrossRef] [PubMed]

9. Jensen, L.; Mueller, T.; Tate, K.; Ross, D.; Magid, J.; Nielsen, N. Soil surface $\mathrm{CO}_{2}$ flux as an index of soil respiration in situ: A comparison of two chamber methods. Soil. Biol. Biochem. 1996, 28, 1297-1306. [CrossRef]

10. Oertel, C.; Matschullat, J.; Zurba, K.; Zimmermann, F.; Erasmi, S. Greenhouse gas emissions from soils-A review. Chem. Erde Geochem. 2016, 76, 327-352. [CrossRef]

11. Wang, S.; Wang, H. Response of soil respiration to a severe drought in Chinese Eucalyptus plantations. J. For. Res. 2017, 28, 841-847. [CrossRef]

12. Duarte, C.M.; Losada, I.J.; Hendriks, I.E.; Mazarrasa, I.; Marbà, N. The role of coastal plant communities for climate change mitigation and adaptation. Nat. Clim. Chang. 2013, 3, 961. [CrossRef]

13. IPCC. Climate Change 2007-The Physical Science Basis: Working Group I Contribution to the Fourth Assessment Report of the IPCC; Cambridge University Press: Cambridge, UK, 2007; Volume 4.

14. Cui, Y.Q.; Jianying, M.A.; Sun, W. Application of stable isotope techniques to the study of soil salinization. J. Arid Land 2011, 3, 285-291. [CrossRef] 
15. Tiunov, A. Stable isotopes of carbon and nitrogen in soil ecological studies. Biol. Bull. 2007, 34, $395-407$. [CrossRef]

16. Robinson, D. $\delta^{15} \mathrm{~N}$ as an integrator of the nitrogen cycle. Trends Ecol. Evol. 2001, 16, 153-162. [CrossRef]

17. Boutton, T.W.; Archer, S.R.; Midwood, A.J.; Zitzer, S.F.; Bol, R. $\delta^{13} \mathrm{C}$ values of soil organic carbon and their use in documenting vegetation change in a subtropical savanna ecosystem. Geoderma 1998, 82, 5-41. [CrossRef]

18. Busari, M.; Salako, F.; Tuniz, C. Stable isotope technique in the evaluation of tillage and fertilizer effects on soil carbon and nitrogen sequestration and water use efficiency. Eur. J. Agron. 2016, 73, 98-106. [CrossRef]

19. Snider, D.M.; Venkiteswaran, J.J.; Schiff, S.L.; Spoelstra, J. A new mechanistic model of $\delta^{18} \mathrm{O}-\mathrm{N}_{2} \mathrm{O}$ formation by denitrification. Geochim. Cosmochim. Acta 2013, 112, 102-115. [CrossRef]

20. Coplen, T.B. Guidelines and recommended terms for expression of stable-isotope-ratio and gas-ratio measurement results. Rapid Commun. Mass Spectrom. 2011, 25, 2538-2560. [CrossRef]

21. Koba, K.; Osaka, K.; Tobari, Y.; Toyoda, S.; Ohte, N.; Katsuyama, M.; Suzuki, N.; Itoh, M.; Yamagishi, H.; Kawasaki, M. Biogeochemistry of nitrous oxide in groundwater in a forested ecosystem elucidated by nitrous oxide isotopomer measurements. Geochim. Cosmochim. Acta 2009, 73, 3115-3133. [CrossRef]

22. Farquhar, G.D.; Ehleringer, J.R.; Hubick, K.T. Carbon isotope discrimination and photosynthesis. Annu. Rev. Plant Biol. 1989, 40, 503-537. [CrossRef]

23. Vogel, J.C. Fractionation of the carbon isotopes during photosynthesis. In Fractionation of the Carbon Isotopes During Photosynthesis; Springer: New York, NY, USA, 1980; pp. 5-29.

24. O'Leary, M.H. Carbon isotopes in photosynthesis. Bioscience 1988, 38, 328-336. [CrossRef]

25. Bernoux, M.; Cerri, C.C.; Neill, C.; de Moraes, J.F. The use of stable carbon isotopes for estimating soil organic matter turnover rates. Geoderma 1998, 82, 43-58. [CrossRef]

26. Kuzyakov, Y. Sources of $\mathrm{CO}_{2}$ efflux from soil and review of partitioning methods. Soil. Biol. Biochem. 2006, 38, 425-448. [CrossRef]

27. Zhang, Y.; Ding, W.; Luo, J.; Donnison, A. Changes in soil organic carbon dynamics in an Eastern Chinese coastal wetland following invasion by a $C_{4}$ plant Spartina alterniflora. Soil. Biol. Biochem. 2010, 42, 1712-1720. [CrossRef]

28. Wrage, N.; Velthof, G.; Van Beusichem, M.; Oenema, O. Role of nitrifier denitrification in the production of nitrous oxide. Soil. Boil. Biochem. 2001, 33, 1723-1732. [CrossRef]

29. Shi, W.-Y.; Tateno, R.; Zhang, J.-G.; Wang, Y.-L.; Yamanaka, N.; Du, S. Response of soil respiration to precipitation during the dry season in two typical forest stands in the forest-grassland transition zone of the Loess Plateau. Agric. For. Meteorol. 2011, 151, 854-863. [CrossRef]

30. Ramachandran Nair, P.K.; Mohan Kumar, B.; Nair, V.D. Agroforestry as a strategy for carbon sequestration. J. Plant Nutr. Soil Sci. 2009, 172, 10-23. [CrossRef]

31. de Stefano, A.; Jacobson, M.G. Soil carbon sequestration in agroforestry systems: A meta-analysis. Agrofor. Syst. 2018, 92, 285-299. [CrossRef]

32. Burras, C.L.; Kimble, J.M.; Lal, R.; Mausbach, M.J.; Uehara, G.; Cheng, H.; Kissel, D.E.; Luxmoore, R.J.; Rice, C.W.; Wilding, L.P. Carbon sequestration: Position of the Soil Science Society of America. Carbon 2001, 25, 10.

33. Amundson, R.; Stern, L.; Baisden, T.; Wang, Y. The isotopic composition of soil and soil-respired $\mathrm{CO}_{2}$. Geoderma 1998, 82, 83-114. [CrossRef]

34. Balesdent, J.; Mariotti, A.; Guillet, B. Natural ${ }^{13} \mathrm{C}$ abundance as a tracer for studies of soil organic matter dynamics. Soil Biol. Biochem. 1987, 19, 25-30. [CrossRef]

35. Drewer, J.; Dufossé, K.; Skiba, U.M.; Gabrielle, B. Changes in isotopic signatures of soil carbon and $\mathrm{CO}_{2}$ respiration immediately and one year after Miscanthus removal. Gcb Bioenergy 2016, 8, 59-65. [CrossRef]

36. Pendall, E.; King, J.Y. Soil organic matter dynamics in grassland soils under elevated $\mathrm{CO}_{2}$ : Insights from long-term incubations and stable isotopes. Soil Biol. Biochem. 2007, 39, 2628-2639. [CrossRef]

37. Zhang, G.; Yu, H.; Fan, X.; Ma, J.; Xu, H. Carbon isotope fractionation reveals distinct process of $\mathrm{CH}_{4}$ emission from different compartments of paddy ecosystem. Sci. Rep. 2016, 6, 27065. [CrossRef] [PubMed]

38. Ciais, P.; Sabine, C.; Bala, G.; Bopp, L.; Brovkin, V.; Canadell, J.; Chhabra, A.; DeFries, R.; Galloway, J.; Heimann, M. Carbon and other biogeochemical cycles. In Climate Change 2013: The Physical Science Basis. Contribution of Working Group I to the Fifth Assessment Report of the Intergovernmental Panel on Climate Change; Cambridge University Press: Cambridge, UK, 2013; pp. 465-570. 
39. Lelieveld, J.; Crutzen, P.J.; Dentener, F.J. Changing concentration, lifetime and climate forcing of atmospheric methane. Tellus B 1998, 50, 128-150. [CrossRef]

40. Zhang, G.; Yu, H.; Fan, X.; Liu, G.; Ma, J.; Xu, H. Effect of rice straw application on stable carbon isotopes, methanogenic pathway, and fraction of $\mathrm{CH}_{4}$ oxidized in a continuously flooded rice field in winter season. Soil Biol. Biochem. 2015, 84, 75-82. [CrossRef]

41. Ogle, S.M.; Breidt, F.J.; Paustian, K. Agricultural management impacts on soil organic carbon storage under moist and dry climatic conditions of temperate and tropical regions. Biogeochemistry 2005, 72, 87-121. [CrossRef]

42. Bilek, R.S.; Tyler, S.C.; Sass, R.L.; Fisher, F.M. Differences in $\mathrm{CH}_{4}$ oxidation and pathways of production

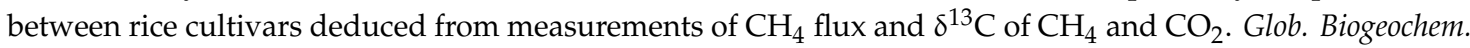
Cycles 1999, 13, 1029-1044. [CrossRef]

43. Whiticar, M.J. Carbon and hydrogen isotope systematics of bacterial formation and oxidation of methane. Chem. Geol. 1999, 161, 291-314. [CrossRef]

44. Krüger, M.; Eller, G.; Conrad, R.; Frenzel, P. Seasonal variation in pathways of $\mathrm{CH}_{4}$ production and in $\mathrm{CH}_{4}$ oxidation in rice fields determined by stable carbon isotopes and specific inhibitors. Glob. Chang. Biol. 2002, 8, 265-280. [CrossRef]

45. Uzaki, M.; Mizutani, H.; Wada, E. Carbon isotope composition of $\mathrm{CH}_{4}$ from rice paddies in Japan. Biogeochemistry 1991, 13, 159-175. [CrossRef]

46. Tyler, S.C.; Brailsford, G.W.; Yagi, K.; Minami, K.; Cicerone, R.J. Seasonal variations in methane flux and $\delta^{13} \mathrm{CH}_{4}$ values for rice paddies in Japan and their implications. Glob. Biogeochem. Cycles 1994, 8, 1-12. [CrossRef]

47. Bergamaschi, P. Seasonal variations of stable hydrogen and carbon isotope ratios in methane from a Chinese rice paddy. J. Geophys. Res. Atmos. 1997, 102, 25383-25393. [CrossRef]

48. Chanton, J.; Whiting, G.; Blair, N.; Lindau, C.; Bollich, P. Methane emission from rice: Stable isotopes, diurnal variations, and $\mathrm{CO}_{2}$ exchange. Glob. Biogeochem. Cycles 1997, 11, 15-27. [CrossRef]

49. Tyler, S.; Bilek, R.; Sass, R.; Fisher, F. Methane oxidation and pathways of production in a Texas paddy field deduced from measurements of flux, $\delta^{13} \mathrm{C}$, and $\delta \mathrm{D}$ of $\mathrm{CH}_{4}$. Glob. Biogeochem. Cycles 1997, 11, 323-348. [CrossRef]

50. Marik, T.; Fischer, H.; Conen, F.; Smith, K. Seasonal variations in stable carbon and hydrogen isotope ratios in methane from rice fields. Glob. Biogeochem. Cycles 2002, 16, 41-1-41-11. [CrossRef]

51. Krüger, M.; Frenzel, P. Effects of $\mathrm{N}$-fertilisation on $\mathrm{CH}_{4}$ oxidation and production, and consequences for $\mathrm{CH}_{4}$ emissions from microcosms and rice fields. Glob. Chang. Biol. 2003, 9, 773-784. [CrossRef]

52. Conrad, R.; Klose, M. Effect of potassium phosphate fertilization on production and emission of methane and its ${ }^{13} \mathrm{C}$-stable isotope composition in rice microcosms. Soil Biol. Biochem. 2005, 37, 2099-2108. [CrossRef]

53. Zhang, G.; Ji, Y.; Ma, J.; Xu, H.; Cai, Z.; Yagi, K. Intermittent irrigation changes production, oxidation, and emission of $\mathrm{CH}_{4}$ in paddy fields determined with stable carbon isotope technique. Soil Biol. Biochem. 2012, 52, 108-116. [CrossRef]

54. Zhang, G.; Ji, Y.; Liu, G.; Ma, J.; Xu, H. Carbon isotope fractionation during $\mathrm{CH}_{4}$ transport in paddy fields. Sci. China Earth Sci. 2014, 57, 1664-1670. [CrossRef]

55. Ravishankara, A.; Daniel, J.S.; Portmann, R.W. Nitrous oxide $\left(\mathrm{N}_{2} \mathrm{O}\right)$ : The dominant ozone-depleting substance emitted in the 21st century. Science 2009, 326, 123-125. [CrossRef]

56. Montzka, S.A.; Dlugokencky, E.J.; Butler, J.H. Non- $\mathrm{CO}_{2}$ greenhouse gases and climate change. Nature 2011, 476, 43-50. [CrossRef] [PubMed]

57. Zhang, W.; Li, Y.; $\mathrm{Xu}, \mathrm{C}$.; Li, Q.; Lin, W. Isotope signatures of $\mathrm{N}_{2} \mathrm{O}$ emitted from vegetable soil: Ammonia oxidation drives $\mathrm{N}_{2} \mathrm{O}$ production in $\mathrm{NH}_{4^{+}}$-fertilized soil of North China. Sci. Rep. 2016, 6, 29257. [CrossRef] [PubMed]

58. Nishimura, S.; Sawamoto, T.; Akiyama, H.; Sudo, S.; Cheng, W.; Yagi, K. Continuous, automated nitrous oxide measurements from paddy soils converted to upland crops. Soil Sci. Soc. Am. J. 2005, 69, 1977-1986. [CrossRef]

59. Bateman, E.; Baggs, E. Contributions of nitrification and denitrification to $\mathrm{N}_{2} \mathrm{O}$ emissions from soils at different water-filled pore space. Biol. Fertil. Soils 2005, 41, 379-388. [CrossRef]

60. Lewicka-Szczebak, D.; Well, R.; Köster, J.R.; Fuß, R.; Senbayram, M.; Dittert, K.; Flessa, H. Experimental determinations of isotopic fractionation factors associated with $\mathrm{N}_{2} \mathrm{O}$ production and reduction during denitrification in soils. Geochim. Cosmochim. Acta 2014, 134, 55-73. [CrossRef] 
61. Firestone, M.; Davidson, E. Microbial basis of $\mathrm{NO}$ and $\mathrm{N}_{2} \mathrm{O}$ production and consumption. In Exchange of Trace Gases between Ecosystems and the Atmosphere: Report of the Dahlem Workshop; Andreae, M.O., Schimel, D.S., Eds.; Wiley: New York, NY, USA, 1989; pp. 7-21.

62. Toyoda, S.; Yoshida, N.; Koba, K. Isotopocule analysis of biologically produced nitrous oxide in various environments. Mass Spectr. Rev. 2017, 36, 135-160. [CrossRef]

63. Schmidt, H.L.; Werner, R.A.; Yoshida, N.; Well, R. Is the isotopic composition of nitrous oxide an indicator for its origin from nitrification or denitrification? A theoretical approach from referred data and microbiological and enzyme kinetic aspects. Rapid Commun. Mass Spectrom. 2004, 18, 2036-2040.

64. Smemo, K.A.; Ostrom, N.E.; Opdyke, M.R.; Ostrom, P.H.; Bohm, S.; Robertson, G.P. Improving process-based estimates of $\mathrm{N}_{2} \mathrm{O}$ emissions from soil using temporally extensive chamber techniques and stable isotopes. Nutr. Cycl. Agroecosyst. 2011, 91, 145-154. [CrossRef]

65. Toyoda, S.; Mutobe, H.; Yamagishi, H.; Yoshida, N.; Tanji, Y. Fractionation of $\mathrm{N}_{2} \mathrm{O}$ isotopomers during production by denitrifier. Soil Biol. Biochem. 2005, 37, 1535-1545. [CrossRef]

66. Sutka, R.L.; Ostrom, N.; Ostrom, P.; Breznak, J.; Gandhi, H.; Pitt, A.; Li, F. Distinguishing nitrous oxide production from nitrification and denitrification on the basis of isotopomer abundances. Appl. Environ. Microb. 2006, 72, 638-644. [CrossRef]

67. Pérez, T.; Garcia-Montiel, D.; Trumbore, S.; Tyler, S.; de Camargo, P.; Moreira, M.; Piccolo, M.; Cerri, C. Nitrous oxide nitrification and denitrification ${ }^{15} \mathrm{~N}$ enrichment factors from Amazon forest soils. Ecol. Appl. 2006, 16, 2153-2167. [CrossRef]

68. Barton, L.; McLay, C.; Schipper, L.; Smith, C. Annual denitrification rates in agricultural and forest soils: A review. Soil Res. 1999, 37, 1073-1094. [CrossRef]

69. Snider, D.M.; Schiff, S.L.; Spoelstra, J. ${ }^{15} \mathrm{~N} /{ }^{14} \mathrm{~N}$ and ${ }^{18} \mathrm{O} /{ }^{16} \mathrm{O}$ stable isotope ratios of nitrous oxide produced during denitrification in temperate forest soils. Geochim. Cosmochim. Acta 2009, 73, 877-888. [CrossRef]

70. Peri, P.L.; Ladd, B.; Pepper, D.A.; Bonser, S.P.; Laffan, S.W.; Amelung, W. Carbon $\left(\delta^{13} C\right)$ and nitrogen $\left(\delta^{15} N\right)$ stable isotope composition in plant and soil in S outhern P atagonia's native forests. Glob. Chang. Biol. 2012, 18, 311-321. [CrossRef]

71. Lee, X.; Feng, Z.; Guo, L.; Wang, L.; Jin, L.; Huang, Y.; Chopping, M.; Huang, D.; Jiang, W.; Jiang, Q. Carbon isotope of bulk organic matter: A proxy for precipitation in the arid and semiarid central East Asia. Glob. Biogeochem. Cycles 2005, 19. [CrossRef]

72. Zhang, Q.; Wu, J.; Lei, Y.; Yang, F.; Zhang, D.; Zhang, K.; Zhang, Q.; Cheng, X. Agricultural land use change impacts soil $\mathrm{CO}_{2}$ emission and its ${ }^{13} \mathrm{C}$-isotopic signature in central China. Soil Tillage Res. 2018, 177, $105-112$. [CrossRef]

73. Vitória, A.P.; Ávila-Lovera, E.; de Oliveira Vieira, T.; do Couto-Santos, A.P.L.; Pereira, T.J.; Funch, L.S.; Freitas, L.; de Miranda, L.D.A.P.; Rodrigues, P.J.P.; Rezende, C.E. Isotopic composition of leaf carbon $\left(\delta^{13} \mathrm{C}\right)$ and nitrogen $\left(\delta^{15} \mathrm{~N}\right)$ of deciduous and evergreen understorey trees in two tropical Brazilian Atlantic forests. J. Trop. Ecol. 2018, 34, 145-156. [CrossRef]

74. Brüggemann, N.; Gessler, A.; Kayler, Z.; Keel, S.; Badeck, F.; Barthel, M.; Boeckx, P.; Buchmann, N.; Brugnoli, E.; Esperschütz, J. Carbon allocation and carbon isotope fluxes in the plant-soil-atmosphere continuum: A review. Biogeosciences 2011, 8, 3457-3489. [CrossRef]

75. Dijkstra, P.; Ishizu, A.; Doucett, R.; Hart, S.C.; Schwartz, E.; Menyailo, O.V.; Hungate, B.A. ${ }^{13} \mathrm{C}$ and ${ }^{15} \mathrm{~N}$ natural abundance of the soil microbial biomass. Soil Biol. Biochem. 2006, 38, 3257-3266. [CrossRef]

76. Wynn, J.G.; Bird, M.I. Environmental controls on the stable carbon isotopic composition of soil organic carbon: Implications for modelling the distribution of $\mathrm{C}_{3}$ and $\mathrm{C}_{4}$ plants, Australia. Tellus B Chem. Phys. Meteorol. 2008, 60, 604-621. [CrossRef]

77. Koch, P.L.; Fox, L.R. Browsing impacts on the stable isotope composition of chaparral plants. Ecosphere 2017, 8, e01686. [CrossRef]

78. Radajewski, S.; Ineson, P.; Parekh, N.; Murrell, J. Stable-isotope probing as a tool in microbial ecology. Nature 2000, 403, 646-649. [CrossRef] [PubMed]

79. Waldrop, M.; Firestone, M. Seasonal dynamics of microbial community composition and function in oak canopy and open grassland soils. Microb. Ecol. 2006, 52, 470-479. [CrossRef] [PubMed]

80. Hornibrook, E.R.; Longstaffe, F.J.; Fyfe, W.S. Spatial distribution of microbial methane production pathways in temperate zone wetland soils: Stable carbon and hydrogen isotope evidence. Geochim. Cosmochim. Acta 1997, 61, 745-753. [CrossRef] 
81. Morse, J.L.; Bernhardt, E.S. Using ${ }^{15} \mathrm{~N}$ tracers to estimate $\mathrm{N}_{2} \mathrm{O}$ and $\mathrm{N}_{2}$ emissions from nitrification and denitrification in coastal plain wetlands under contrasting land-uses. Soil Biol. Biochem. 2013, 57, 635-643. [CrossRef]

82. Bowling, D.R.; Pataki, D.E.; Randerson, J.T. Carbon isotopes in terrestrial ecosystem pools and $\mathrm{CO}_{2}$ fluxes. New Phytol. 2008, 178, 24-40. [CrossRef]

83. Conrad, R. Quantification of methanogenic pathways using stable carbon isotopic signatures: A review and a proposal. Org. Geochem. 2005, 36, 739-752. [CrossRef]

84. Andersson, R.A.; Meyers, P.; Hornibrook, E.; Kuhry, P.; Mörth, C.M. Elemental and isotopic carbon and nitrogen records of organic matter accumulation in a Holocene permafrost peat sequence in the East European Russian Arctic. J. Quat. Sci. 2012, 27, 545-552. [CrossRef]

85. Mu, C.; Zhang, T.; Wu, Q.; Peng, X.; Zhang, P.; Yang, Y.; Hou, Y.; Zhang, X.; Cheng, G. Dissolved organic carbon, $\mathrm{CO}_{2}$, and $\mathrm{CH}_{4}$ concentrations and their stable isotope ratios in thermokarst lakes on the Qinghai-Tibetan Plateau. J. Limnol. 2016, 75, 313-319. [CrossRef]

86. Chen, C.; Wei, J.; Wen, X.; Sun, X.; Guo, Q. Photosynthetic Carbon Isotope Discrimination and Effects on Daytime NEE Partitioning in a Subtropical Mixed Conifer Plantation. Agric. For. Meteorol. 2019, 272, 143-155. [CrossRef]

87. Cisneros-Dozal, L.; Trumbore, S.E.; Hanson, P. Partitioning sources of soil-respired $\mathrm{CO}_{2}$ and their seasonal variation using a unique radiocarbon tracer. Glob. Chang. Biol. 2006, 12, 194-204. [CrossRef]

88. Ogée, J.; Peylin, P.; Cuntz, M.; Bariac, T.; Brunet, Y.; Berbigier, P.; Richard, P.; Ciais, P. Partitioning net ecosystem carbon exchange into net assimilation and respiration with canopy-scale isotopic measurements: An error propagation analysis with ${ }^{13} \mathrm{CO}_{2}$ and $\mathrm{CO}^{18} \mathrm{O}$ data. Glob. Biogeochem. Cycles. 2003, 17. [CrossRef]

89. Badeck, F.W.; Tcherkez, G.; Nogues, S.; Piel, C.; Ghashghaie, J. Post-photosynthetic fractionation of stable carbon isotopes between plant organs-A widespread phenomenon. Rapid Commun. Mass Spectrom. 2005, 19, 1381-1391. [CrossRef] [PubMed]

90. Bowling, D.R.; Tans, P.P.; Monson, R.K. Partitioning net ecosystem carbon exchange with isotopic fluxes of $\mathrm{CO}_{2}$. Glob. Chang. Biol. 2001, 7, 127-145. [CrossRef]

91. Fassbinder, J.J.; Griffis, T.J.; Baker, J.M. Evaluation of carbon isotope flux partitioning theory under simplified and controlled environmental conditions. Agric. For. Meteorol. 2012, 153, 154-164. [CrossRef]

92. Baldocchi, D.; Bowling, D. Modelling the discrimination of ${ }^{13} \mathrm{CO}_{2}$ above and within a temperate broad-leaved forest canopy on hourly to seasonal time scales. Plant Cell Environ. 2003, 26, 231-244. [CrossRef]

93. Griffis, T.J. Tracing the flow of carbon dioxide and water vapor between the biosphere and atmosphere: A review of optical isotope techniques and their application. Agric. For. Meteorol. 2013, 174, 85-109. [CrossRef]

94. Baggs, E. Partitioning the components of soil respiration: A research challenge. Plant Soil 2006, 284, 1-5. [CrossRef]

95. Conrad, R. Methanogenic microbial communities associated with aquatic plants. In Plant Surface Microbiology; Springer: New York, NY, USA, 2008; pp. 35-50.

96. Shrestha, M.; Abraham, W.R.; Shrestha, P.M.; Noll, M.; Conrad, R. Activity and composition of methanotrophic bacterial communities in planted rice soil studied by flux measurements, analyses of pmoA gene and stable isotope probing of phospholipid fatty acids. Environ. Microb. 2008, 10, 400-412. [CrossRef]

97. Lu, Y.; Murase, J.; Watanabe, A.; Sugimoto, A.; Kimura, M. Linking microbial community dynamics to rhizosphere carbon flow in a wetland rice soil. FEMS Microb. Ecol. 2004, 48, 179-186. [CrossRef]

98. Zhang, Q.; Zhou, J.; Li, X.; Liu, C.; Lin, W.; Zheng, W.; Chen, Y.; Yang, Y. Nitrogen addition accelerates the nitrogen cycle in a young subtropical Cunninghamia lanceolata (Lamb.) plantation. Ann. For. Sci. 2019, 76, 31. [CrossRef]

99. Vallano, D.M.; Sparks, J.P. Foliar $\delta^{15} \mathrm{~N}$ is affected by foliar nitrogen uptake, soil nitrogen, and mycorrhizae along a nitrogen deposition gradient. Oecologia 2013, 172, 47-58. [CrossRef] [PubMed]

100. Cheng, W.; Parton, W.J.; Gonzalez-Meler, M.A.; Phillips, R.; Asao, S.; McNickle, G.G.; Brzostek, E.; Jastrow, J.D. Synthesis and modeling perspectives of rhizosphere priming. New Phytol. 2014, 201, 31-44. [CrossRef] [PubMed]

101. Craine, J.M.; Morrow, C.; Fierer, N. Microbial nitrogen limitation increases decomposition. Ecology 2007, 88, 2105-2113. [CrossRef] [PubMed]

102. Paterson, E.; Gebbing, T.; Abel, C.; Sim, A.; Telfer, G. Rhizodeposition shapes rhizosphere microbial community structure in organic soil. New Phytol. 2007, 173, 600-610. [CrossRef] [PubMed] 
103. Subke, J.-A.; Hahn, V.; Battipaglia, G.; Linder, S.; Buchmann, N.; Cotrufo, M.F. Feedback interactions between needle litter decomposition and rhizosphere activity. Oecologia 2004, 139, 551-559. [CrossRef]

104. Murphy, C.J.; Baggs, E.M.; Morley, N.; Wall, D.P.; Paterson, E. Rhizosphere priming can promote mobilisation of N-rich compounds from soil organic matter. Soil Biol. Biochem. 2015, 81, 236-243. [CrossRef]

105. Pausch, J.; Loeppmann, S.; Kühnel, A.; Forbush, K.; Kuzyakov, Y.; Cheng, W. Rhizosphere priming of barley with and without root hairs. Soil Biol. Biochem. 2016, 100, 74-82. [CrossRef]

106. Prévost-Bouré, N.C.; Soudani, K.; Damesin, C.; Berveiller, D.; Lata, J.-C.; Dufrêne, E. Increase in aboveground fresh litter quantity over-stimulates soil respiration in a temperate deciduous forest. Appl. Soil Ecol. 2010, 46, 26-34. [CrossRef]

107. Xu, Q.; Wang, X.; Tang, C. Wheat and white lupin differ in rhizosphere priming of soil organic carbon under elevated $\mathrm{CO}_{2}$. Plant Soil 2017, 421, 43-55. [CrossRef]

108. Lloyd, D.A.; Ritz, K.; Paterson, E.; Kirk, G.J. Effects of soil type and composition of rhizodeposits on rhizosphere priming phenomena. Soil Biol. Biochem. 2016, 103, 512-521. [CrossRef]

109. Thurgood, A.; Singh, B.; Jones, E.; Barbour, M.M. Temperature sensitivity of soil and root respiration in contrasting soils. Plant Soil 2014, 382, 253-267. [CrossRef]

110. Sun, Y.; Xu, X.; Kuzyakov, Y. Mechanisms of rhizosphere priming effects and their ecological significance. J. Plant Ecol. 2014, 38, 62-75.

111. Lin, W.; Fang, F.; Zhang, W.; Ding, J.; Li, Y.; Xu, C.; Li, Q. A review on development of stable isotope technique in the studies of $\mathrm{N}_{2} \mathrm{O}$ formation mechanism. J. Appl. Ecol. 2017, 28, 2344-2352.

112. Yin, L.; Dijkstra, F.; Wang, P.; Zhu, B.; Cheng, W. Rhizosphere priming effects on soil carbon and nitrogen dynamics among tree species with and without intraspecific competition. New Phytol. 2018, 218, 1036-1048. [CrossRef] [PubMed]

113. Ciotoli, G.; Etiope, G.; Marra, F.; Florindo, F.; Giraudi, C.; Ruggiero, L. Tiber delta $\mathrm{CO}_{2}-\mathrm{CH}_{4}$ degassing: A possible hybrid, tectonically active sediment-hosted geothermal system near rome. J. Geophys. Res. Soil Eerth 2016, 121, 48-69. [CrossRef]

(C) 2019 by the authors. Licensee MDPI, Basel, Switzerland. This article is an open access article distributed under the terms and conditions of the Creative Commons Attribution (CC BY) license (http://creativecommons.org/licenses/by/4.0/). 